\title{
O SISTEMA INQUISITÓRIO NO PROCESSO PENAL BRASILEIRO
}

\author{
Reinaldo Santos de Almeida Júnior* \\ "La veritá è nel tutto, non nella parte; e il tutto è \\ troppo per noi", \\ (Francesco Carnelutti)
}

SUMÁRIO: 1. INTRODUÇÃO. 2. OS SISTEMAS PUROS: PRINCÍPIO INQUISITIVO E DISPOSITIVO. 3. O PRINCÍPIO UNIFICADOR: A GESTÃO DA PROVA. 3.1. O SISTEMA INQUISITÓRIO BRASILEIRO. 3.2. A REFORMA DO CPP COM AS ALTERAÇÕES DAS LEIS 11.689, 11.690 E 11.719: 'MUDAR PARA FICAR TUDO COMO ESTÁ'. 4. O CONTEÚDO DO PROCESSO PENAL: CRÍTICAS À TEORIA GERAL DO PROCESSO. 5. A JUSTIÇA NEGOCIAL. 6. CONSIDERAÇÕES FINAIS. 7. REFERÊNCIAS BIBLIOGRÁFICAS.

\begin{abstract}
RESUMO
O objeto do artigo apresenta a análise sucinta do sistema processual vigente no processo penal brasileiro com o Código de Processo Penal editado sob os auspícios reacionários de Francisco de Campos no decreto-lei no 3.689 de 3 de outubro de 1941 e as recentes alterações legislativas das Leis $11.689,11.690$ e 11.719 que sustentam a manutenção das feições inquisitoriais na essência do sistema de imputação de fatos puníveis brasileiro. A partir da noção kantiana de sistema, da classificação dos sistemas processuais sob o critério da gestão da prova e a essência do sistema processual brasileiro no Código de Processo Penal de 1941, realiza-se uma análise das inovações legislativas com as recentes reformas do Código, num contexto em que foi constituída uma comissão de juristas pelo Parlamento com a finalidade de redigir um anteprojeto de Novo Código de Processo Penal.
\end{abstract}

Palavras-chave: processo penal; sistemas processuais; princípio inquisitivo.

${ }^{*}$ Estudante do $5^{\circ}$ ano noturno da Faculdade de Direito da Universidade Federal do Paraná (UFPR). Programa de Educação Tutorial PET/Direito. Bolsista do CNPq (2009/2010). Monitor de Direito Penal A (2009); Direito Penal C (2009) e Direito Processual Penal A (2009). E-mail: rei.sajr@gmail.com.

${ }^{1}$ CARNELUTTI, Francesco. Verità, dubbio, certezza. Rivista di Diritto Processuale, Padova, v. 200, p. 5, 1965. 


\section{INTRODUÇÃ̃O}

O sistema inquisitório tem raízes no período de decadência da velha Roma, porém, nasce, na forma como estudamos hoje, no seio da Igreja Católica, e "trata-se, sem dúvida, do maior engenho jurídico que o mundo conheceu; e conhece",2.

Com o final do Império Romano e a aglutinação das populações em feudos em busca de segurança institui-se o modo de produção da vida medieval, regido pela descentralização política e uma sociedade estruturada em classes composta por suseranos, os senhores feudais detentores de domínios e bens de produção, e vassalos, os súditos que dedicavam sua fidelidade e trabalho no ato de homenagem - como "bem de troca" ${ }^{3}$ - à investidura composta por benefícios e terras no sistema de produção feudal. Ainda, figuravam os cavaleiros, tidos como o braço armado do poder, e os clérigos, que constituíam a classe letrada e iluminada, a qual monopolizava o saber e acesso às escrituras sagradas, para delas, extrair o poder com a interpretação privilegiada, em face da inacessibilidade aos meios de informações, por parte da população ${ }^{4}$.

Conforme as lições de Miranda Coutinho:

com o domínio dos bárbaros e o fenômeno da recepção do direito romano, o sistema processual penal, apesar das nuanças, manteve-se estruturado nos chamados Juízos de Deus, basicamente nas fórmulas do juramento (em geral para os que mais possuíam), do duelo (de regra para os mais hábeis nas ações agonísticas) e das ordálias, para o povo em geral. Nada impedia que assim se mantivesse, até porque as fórmulas germânicas primitivas, por exemplo, embora nas raízes fossem fundadas em princípio de moral, logo foram 'domesticadas', para serem laboradas em nome de Deus, que deitaria luz para proteger os inocentes; e

${ }^{2}$ MIRANDA COUTINHO, Jacinto Nelson de. O papel do novo juiz no processo penal. Crítica à teoria geral do direito processual penal. Rio de Janeiro: Renovar, 2001. p. 13.

\footnotetext{
${ }^{3}$ A palavra "feudo", de origem germânica, expressa "bem dado em troca".

${ }^{4}$ MIRANDA COUTINHO, op. cit., loc. cit.
} 
manter o sistema de poder 5 .

Destarte, sob o pretexto de argumento de combate à heresia, que punha em dúvida os dogmas do catolicismo e constituía ameaça ao poder supremo da Igreja, o Papa Inocêncio III ordena uma cruzada contra os Albigenses, a qual se inicia em 1209, referenciada pelo IV Concílio de Latrão em 1215, com a constituição dos Tribunais de Inquisição, cuja base jurídica residiu na Constitutio Excomuniamus (1231), do Papa Gregório IX, para consolidar-se com a Bula Ad extirpanda, de Inocêncio IV, em $1252^{6}$.

Daí, com efeito, afirma Vèlez Mariconde que:

desde entonces (inquisitio significa pesquisa que se cumple por escrito y secretamente, y al término de la cual se dicta la sentencia), el proceso cambia fundamentalmente de fisionomía; lo que era un duelo leal y franco entre acusador y acusado, armados de iguales poderes, se torna en lucha desigual entre juez y acusado. El primero abandona su posición de árbitro y asume la activa de inquisidor, actuando desde el primer momento también como acusador, es decir, se confundem las actividades del juez y del acusador; por su parte, el acusado pierde la condición de verdadero sujeto procesal y se convierte en objeto de una dura persecusión ${ }^{7}$.

\footnotetext{
${ }^{5}$ Ibidem, p. 14.

${ }^{6}$ MIRANDA COUTINHO, op. cit., p. 15.
}

7 VÉLEZ MARICONDE, Alfredo. El proceso penal inquisitivo. Scritti giuridici in memoria de Piero Calamandrei. Padova: Cedam, 1958. v. 2, p. 510. [tradução livre: desde então (inquisitio significa investigação que se cumpre por escrito e secretamente, e ao término do qual se dita a sentença), o processo muda fundamentalmente de fisionomia; o que era um duelo leal e franco entre acusador e acusado, armados de iguais poderes, se torna uma luta desigual entre juiz e acusador. $\mathrm{O}$ primeiro abandona a sua posição de árbitro e assume a posição ativa de inquisidor, atuando desde o primeiro momento também como acusador, isto é, se confundem com as atividades do juiz e do acusador; de sua parte, o acusador perder a condição de verdadeira sujeito processual e se converte em objeto de uma dura persecução]. 


\section{OS SISTEMAS PUROS: PRINCÍPIOS INQUISITIVO E DISPOSITIVO}

De acordo com a doutrina clássica, pode-se determinar o sistema processual vigente com fundamento em seu princípio constitutivo, o qual é capaz de determinar a configuração dos modelos históricos existentes sob a denominação inquisitória, acusatória e mista ${ }^{8}$.

Assim, o princípio inquisitivo representaria a concentração dos poderes e funções de acusar, defender e julgar em uma só pessoa: o juiz.

Segundo a doutrina tradicional de Tourinho Filho:

é ele quem inicia, de ofício, o processo, quem recolhe as provas e quem, afinal, profere a decisão, podendo, no curso do processo, submeter o acusado a torturas, a fim de obter a rainha das provas: a confissão. O processo é secreto e escrito. Nenhuma garantia se confere ao acusado. Este aparece em uma situação de tal subordinação, que se transfigura e se transmuda em objeto do processo e não em sujeito de direito ${ }^{9}$.

De tal sorte, podem-se enunciar as seguintes características do princípio inquisitivo: a) a concentração ou superposição de duas ou mais funções: acusar, defender, julgar; b) o sigilo dos atos; c) ausência de contraditório; d) procedimento majoritariamente escrito; e) apreciação da prova segundo o critério da tarifação legal; f) a confissão como elemento cabal e suficiente para a condenação; g) iniciativa $e x$ officio do processo, com a admissão de denúncia anônima.

No processo inquisitório de origem canônica, não raramente a pena do delito era menos grave do que a tortura ${ }^{10}$ a que se submetia o acusado, que desconhecia a acusação que lhe era imputada ${ }^{11}$, num processo que se iniciava de ofício, com a

${ }^{8}$ TOURINHO FILHO, Fernando da Costa. Processo penal. 13. ed. São Paulo: Saraiva, 1992, p. 81; TORNAGHI, Hélio. Curso de processo penal. 4. ed. São Paulo: Saraiva, 1987. v. 1, p. 9.

${ }^{9}$ TOURINHO FILHO, op. cit., p. 83.

${ }^{10}$ Ibidem, p. 76.

11 "Senhor juiz de instrução, o senhor não me perguntou absolutamente nada: brandiu a sua 
finalidade de obter a confissão do crime - "regina probationem -, ainda que mediante emprego de tortura, segundo a crença religiosa de que a "verdade possibilita a rendição dos pecados e a absolvição, ainda que paradoxalmente fosse necessário condenar e, no limite, queimar na fogueira ${ }^{, 12}$.

De outro lado, apresenta-se o princípio dispositivo, representado pela disposição igualitárias das partes, segundo o princípio da paridade de armas, por intermédio da garantia jurídico-política do contraditório, num processo público e oral, com iniciativa que cabe à parte acusadora - a detentora do ônus probatório -, com as funções de acusar, defender e julgar atribuídas a pessoas distintas, com a ampla defesa e todos os recursos e meios a ela inerentes, e a vigência do princípio ne procedat judex ex officio, o qual estabelece o princípio da inércia da jurisdição.

O princípio dispositivo é que rege o sistema acusatório, em "que a prova é avaliada dentro da livre convicção; a sentença passa em julgado e, por fim, a liberdade do acusado é a regra, antes da condenação, até para poder dar conta da prova a ser produzida",

Por fim, o sistema misto, também conhecido sob a denominação de sistema acusatório formal, representaria a coexistência dos princípios inquisitivo e dispositivo, com as etapas de investigação preliminar e de instrução preparatória, sob a égide inquisitorial, e a fase final de julgamento regido pelo processo público, oral e do contraditório $^{14}$.

Na classificação do sistema adotado no processo penal brasileiro, a doutrina divide-se dentre os três sistemas possíveis, e majoritariamente, aponta o sistema misto. É certo, todavia, que se faz necessário afirmar que, com efeito, inexistem sistemas puros, na forma clássica como foram teoricamente estruturados, em qualquer sistema

constatação como uma primeira verdade. Isso caracteriza bem o modo como foi conduzido todo este processo”. In: KAFKA, Franz. O processo. São Paulo: Círculo do Livro, 1991, p. 44.

${ }^{12}$ MIRANDA COUTINHO, op. cit., p. 17.

${ }^{13}$ MIRANDA COUTINHO. Introdução aos princípios gerais do processo penal brasileiro. Revista da Faculdade de Direito, Curitiba, n. 30, p. 170, 2008.

${ }^{14}$ TOURINHO FILHO, op. cit., p. 84. 
processual vigente ${ }^{15}$

\section{O PRINCÍPIO UNIFICADOR: A GESTÃO DA PROVA}

\subsection{O SISTEMA INQUISITÓRIO BRASILEIRO}

Conforme as lições de Miranda Coutinho,

o dito sistema misto é a conjugação dos outros dois, mas não tem um princípio unificador próprio, sendo certo que ou é essencialmente inquisitório (como o nosso), com algo (características secundárias) proveniente do sistema acusatório, ou é essencialmente acusatório, com alguns elementos característicos (novamente secundários) recolhidos do sistema inquisitório ${ }^{16}$.

De tal modo, deve-se extrair a necessária configuração do princípio unificador, capaz de traduzir as características essenciais que dão sustentáculo a cada sistema, com a realização do princípio inquisitivo ou dispositivo, de sorte que só se poderá afirmar a existência de um terceiro sistema formalmente.

Destarte, ao tratar a gestão da prova no sistema inquisitório, Miranda Coutinho afirma a hipótese do juiz que decide antes, num pré-juízo de valor, e depois, sai em busca do material probatório suficiente para confirmar sua versão inicial ${ }^{17}$, de sorte a reafirmar o que Cordero chamou de "quadro mental paranóico" do juiz, com a legitimação da possibilidade de crença no imaginário, tomado como verdadeiro, na

${ }^{15}$ PISAPIA, Gian Domenico. Compendio di procedura penale. 4. ed. Padova: Cedam, 1985, p. 21: "occorre precisare subito che in nessun Paese oggi è più accolto né il sistema accusatorio puro né quello inquisitório" [tradução livre: é necessário afirmar que nenhum País atualmente adota o sistema acusatório nem o modelo inquisitório puros].

\footnotetext{
${ }^{16}$ MIRANDA COUTINHO. O papel do novo juiz ..., p. 11.

${ }^{17}$ Idem. Introdução aos princípios gerais ..., p. 185.
} 
construção do "primato dell'ipotesi sui fatti"18.

Segundo Miranda Coutinho, a gestão da prova é, portanto, a característica fundamental de identificação do princípio unificador do sistema inquisitório, quando confiada essencialmente ao magistrado, que atua como senhor da prova, onipotente, desideologizado, tido como semi-deus no processo penal.

Há aqueles que ainda advogam o mito da neutralidade axiológica - já há muito superado no campo filosófico - corolário da corrente positivista de pensamento, a qual acreditava na possibilidade de isenção do sujeito cognoscente em relação ao objeto cognoscível, por intermédio de um método dotado de cientificidade, capaz de compreender, na integralidade, o objeto, com pretensões de verdades científicas e universais.

Como já observou a doutrina marxista, o discurso é capaz de construir a realidade, posto que quando se define determinada imagem da realidade, ela tem efeitos reais, segundo o teorema de Thomas, e uma prova disto é o próprio poder adstrito ao saber dogmático - compreendido aqui o direito como ideológico ${ }^{19}$ e, essencialmente, discursivo ${ }^{20}$.

${ }^{18}$ CORDERO, F. Guida alla procedura penale. Torino: Utet, 1986, p. 51: "La solitudine in cui gli inquisitori lavorano, mai esposti al contraddittorio, fuori da griglie dialettiche, può darsi che giovi al lavorìo poliziesco ma sviluppa quadri mentali paranoidi. Chiamiamoli 'primato dell'ipotesi sui fatti': chi indaga ne segue una, talvolta a occhi chiusi; niente la garantisce più fondata rispetto alle alternative possibili, né questo mestiere stimola cautela autocritica; siccome tutte le carte sono in mano sua ed è lui che l'ha intavolato, punta sulla 'sua' ipotesi" [tradução livre: a solidão em que os inquisidores trabalham, nunca expostos ao contraditório, fora das construções dialéticas, pode dar-se que o trabalho policialesco se desenvolva num quadro mental paranóico. Chamamo-lhe o primado da hipótese sobre os fatos: quem pergunta segue uma [hipótese], às vezes de olhos fechados; nada a garante mais fundado respeito do que à alternativa possível, nem aquele ofício estimula a cautela autocrítica; como todas as cartas estão na sua mão e é ele que a escolheu, apontada para a sua hipótese].

${ }^{19}$ Cf. POULANTZAS, Nicos. O estado, o poder, o socialismo. Trad. Rita Lima. 2. ed. Rio de Janeiro: Graal, 1985; LYRA FILHO, Roberto. Por que estudar direito, hoje?. Brasília: Nair, 1984.

${ }^{20}$ PERELMAN, Chäim; Olbrechts-Tyteca, Lucie. Tratado da argumentação: a nova retórica. Trad. Maria Ermantina de Almeida Prado Galvão. 2. ed. São Paulo: Martins Fontes, 2005; RODRÍGUEZ, Victor Gabriel. Argumentação jurídica: técnicas de persuasão e lógica informal. 4. ed. São Paulo: Martins Fontes, 2005; ATIENZA, Manuel. As razões do direito: teorias da argumentação jurídica. Trad. Maria Cristina Guimarães Cupertino. São Paulo: Landy, 2006; SANTOS, 
De outro lado, trata-se também do discurso de imparcialidade do juiz, a qual é tida como condição essencial para a decisão justa, nas expressões de Liebman: "l'imparzialità é uma qualità che deve possedere il giudice per compiere l'atto che da lui si atende, cioè per il giudizio, che non puó esse retto, né la decisione giusta, s'egli non é - proprio quando giudica e decide - imparziale" ${ }^{\prime 21}$.

A imparcialidade do juiz como árbitro, diante da aplicação do princípio dispositivo, é o meio que propõe Calamandrei, em "Il processo come giuoco", ainda que tratando do processo civil, por intermédio do conhecimento das regras do jogo, nas seguintes palavras: "regole finale: a chi si proponga um certo scopo (ottener giustizia), offrono il método, o si potrebbe dire il ricettario, per conseguirlo. (...) Questo carattere di giuoco ragionato si manifesta specialmente in quel principio fondamentale del processo che si potrebbe chiamare il principio di dialetticità". ${ }^{22}$

Assim, conforme as lições de Calamandrei, as partes devem, em primeiro lugar, conhecer as regras do jogo e observá-las em funcionamento na prática forense. Todavia, para se obter justiça, não basta somente ter razão.

Nesse ínterim, é que Bobbio, de um ponto de vista procedimentalista e estritamente formal, afirma que a democracia exige a prévia delimitação das regras do jogo ${ }^{23}$.

De toda sorte, Miranda Coutinho pondera que: "a delimitação das regras, não basta! É preciso que se saiba, para além dela, contra quem se está jogando e qual o

Boaventura de Sousa. O discurso e o poder: ensaio sobre a sociologia da retórica. Porto Alegre: Fabris, 1988.

${ }^{21}$ LIEBMAN, Enrico Tullio. Fondamento del principio dispositivo. Rivista di Diritto Processuale, Padova, v. 15, p. 561, 1960. [tradução livre: a imparcialidade é uma qualidade que deve possuir o juiz para cumprir o ato que dele se exige, isto é, para o juízo, que não pode ser correto, nem a decisão justa, se não é, - justamente quando julga e decide - imparcial].

${ }^{22}$ CALAMANDREI, Piero. Il Processo come giuoco. Rivista di Diritto Processuale, Padova, v. 5 (parte prima), p. 24-27, 1950. [tradução livre: regra final - a quem se proponha um certo objetivo (obter justiça), ofereço um método, ou se pode dizer o receituário, para consegui-lo. (...) Esta característica do jogo racional se manifesta especialmente naquele princípio fundamental do processo que se poderia chamar o princípio da dialética].

${ }^{23}$ BOBBIO, Norberto. O futuro da democracia: uma defesa das regras do jogo. Trad. Marco Aurélio Nogueira. 4. ed. Rio de Janeiro: Paz e Terra, 1989. 
conteúdo ético e axiológico do próprio jogo. Como referido no início, alcançar tal patamar só é possível quando os agentes em cena, no palco social, assumem sua face ideológica"24.

E sobre a prática criadora do intérprete, deve-se afirmar na esteira de Faria que “a partir da pretensão de objetividade e neutralidade da dogmática, são ocultados os conflitos socioeconômicos-políticos ${ }^{, 25}$.

Assim, a forma jurídica não pode se destacar do conteúdo desigual do Direito - que situa o critério de criminalização segundo a posição de classe do autor - pois "se o processo for não mais que forma carente de conteúdo tais formalidades careceriam de valor (...) visto que forma é sempre forma de um conteúdo" 26 .

Por fim, restam as sábias palavras de Cordero:

Teoremi. Ne elabora finché vuole l'inquisitore, lavorando in segreto su animali confessanti: concepita um'ipotesi, vi edifica cabale induttive; l'assenza del contraddittorio apre un vuoto lógico aperto al pensiero paranoide; trame lambiccate eclissano i fatti. Padrone del gioco, li dispone sulla scacchiera come gli conviene: l'inquisizione è um mondo verbale símile all'onirico; tempi, luoghi, cose, persone, eventi, fluttuano in quadri manipolabili. (...) Gioco pericoloso: l'elucubrante compone a mano libera, selettivamente attento o sordo ai dati, secondo che convalidino o no l'ipotesi; ed essendo le parole una materia plastica (gli inquisiti ne emettono a fiumi), ogni conclusione risulta posible; l'estro poietico sviluppa un sentimento narcisistico d'onnipotenza nel quale svanisce ogni cautela autocrítica ${ }^{27}$.

${ }^{24}$ MIRANDA COUTINHO. O papel do novo juiz ..., p. 28.

${ }^{25}$ FARIA, José Eduardo. Ordem legal v. mudança social: a crise social do Judiciário e a formação do magistrado. Direito e Justiça: a função social do Judiciário. São Paulo: Ática, 1994, p. 103.

${ }^{26}$ MARX, Karl. La ley sobre los robos de leña. In: Escritos de juventud. México: Fondo de Cultura Econômica, 1987, p. 281-282.

${ }^{27}$ CORDERO, Franco. Procedura penale. Milano: Giufreè, 1991, p. 25. [tradução livre: Teoremas. Elabora-os até que deseje o inquisidor, trabalhando em segredo seus animais confessionários: concebe uma hipótese, vos edifica cabal indução; a ausência do contraditório abre um voto lógico aberto ao pensamento paranóico; tramas atormentadas eclipsam os fatos. Padrão do jogo, dispõe deles sobre o tabuleiro de xadrez como lhe convém: a inquisição é um mundo versal semelhante ao onírico; tempos, lugares, coisas, pessoas, eventos, flutuam em quadros manipuláveis. (...) Jogo perigoso: o elucubrante compõe à mão livre, seletivamente atento ou surdo aos dados, segundo que convalida ou não a hipótese; e sendo a palavra uma matéria flexível (os inquiridos emitem-nas aos rios), cada conclusão resulta possível; a inspiração poética desenvolve um sentimento narcisístico de onipotência no qual desaparece qualquer cautela autocrítica]. 


\subsection{A REFORMA DO CPP COM AS ALTERAÇÕES DAS LEIS 11.689, 11.690 E 11.719: "PARA QUE AS COISAS PERMANEÇAM IGUAIS, É PRECISO QUE TUDO MUDE"}

As recentes alterações no Código de Processo Penal, pelas Leis $n^{\circ} 11.689$, 11.690 e 11.719 referentes ao procedimento do Tribunal do Júri, de prova no processo penal e de suspensão do processo, 'emendatio libelli', 'mutatio libelli' e outros procedimentos, representaram meras mudanças pontuais no processo penal brasileiro.

De fato, tais alterações situam-se muito aquém dos anseios de necessária atualização do Código de Processo Penal de 1941, editado sob os auspícios da ditatura do Estado Novo e do reacionário Francisco de Campos, para compatibilizá-lo à Constituição da República de 1988 e suas garantias.

Atualmente, em que pese a instituição de Comissão de Juristas para a elaboração de um anteprojeto de Código de Processo Penal que deverá ser apresentado ao Senado Federal, as principais conquistas rumo ao sistema acusatório no processo penal brasileiro desde as novas alterações no Código de Processo Penal se deram por via jurisprudencial, como, por exemplo, nos referidos julgados do Supremo Tribunal Federal (STF):

a) No julgamento do $\mathbf{H C} \mathbf{n}^{\circ} \mathbf{8 4 . 0 7 8}$.

Na oportunidade, a Corte reafirmou o princípio da presunção de inocência para consagrar o direito do réu de apelar em liberdade até esgotar as vias recursais pelo trânsito em julgado de sentença penal condenatória, a fim de abolir a inconstitucional 'execução provisória da pena'.

Logo, diante de sentença condenatória, possui o acusado, ora condenado em primeiro grau, o direito de apelar em liberdade, desde que, por óbvio, ausentes os requisitos e fundamentos para decretação da prisão preventiva, a qual, segundo orientação consolidada do STF, não pode ser fundamentada apenas na gravidade, em 
abstrato, do delito ${ }^{28}$, nem na invocação genérica do art. 312 ou de seus fundamentos autorizadores, sem a demonstração concreta de incidência dos mesmos no caso em análise ${ }^{29}$.

b) Na edição da Súmula Vinculante de n⿳ 14.

A fim de garantir o acesso pelo defensor aos elementos de prova já documentados em investigação conduzida por órgão com competência de política judiciária, consignou-se que: “É direito do defensor, no interesse do representado, ter acesso amplo aos elementos de prova que, já documentados em procedimento investigatório realizado por órgão com competência de polícia judiciário, digam respeito ao exercício do direito de defesa".

É certo que, neste caso, ainda existem alguns obstáculos práticos a serem superados, como o atraso voluntário na documentação de diligências já cumpridas e encerradas por parte do Delegado ou a pedido do Juiz inquisidor, a fim de protelar a ciência e conhecimento por parte do acusado - por meio de seu defensor - de investigações intentadas contra ele, bem como possíveis argumentações de excepcionalidade à súmula vinculante, inerentes à natureza da investigação, em casos que a ciência de conclusão de parcela das diligências tornaria, em tese, inútil a (eficácia) da continuidade das investigações.

A par dos avanços construídos pela inteligência jurisprudencial, na essência, as alterações legislativas (por elas) nada mudaram, ou, talvez, mudaram (com elas) para que tudo ficasse igual! E não fosse a militância e perspicácia dos advogados e a corrente da instrumentalidade garantista no Poder Judiciário, quiçá, vivêssemos períodos de maior desesperança no sistema de justiça criminal brasileiro.

${ }^{28} \mathrm{HC} \mathrm{n}^{\circ}$ s. 97.998, Relator o Min. Eros Grau; 83.516, Relator Min.Cezar Peluso, DJ de 23.5.08; 91.662, Relator o Min. Celso de Mello, DJ de 4.4.08; 88.858, Relator o Min. Marco Aurélio, DJ de 25.4.08; 87.343, Relator o Min. Cezar Peluso, DJ de 22.6.07; 84.071, Relator o Min. Cezar Peluso, DJ de 24.11.06; 88.025, Relator o Min. Celso de Mello, DJ de 16.2.07; 85.237, Relator o Min. Celso de Mello, DJ de 29.4.05).

\footnotetext{
${ }^{29} \mathrm{HC}$ n. ${ }^{\text {8 }}$ 85.615, Relator o Min. Gilmar Mendes, DJ 03.03.2006.
} 
Logo, por força do princípio unificador que identifica, em essência, o sistema determinado pelo critério da gestão da prova, o processo penal brasileiro permanece com feições inquisitoriais, ao adotar o princípio inquisitivo, a saber, por meio de infindáveis poderes instrutórios concedidos ao juiz, sob os argumentos da efetividade do processo e do discurso de combate à impunidade, de sorte a desnaturar qualquer possibilidade de processo de partes.

O que importa dizer, neste particular, é que o sistema inquisitivo - e os discursos que fundamentam o ativismo ex officio no processo penal - atinge um grupo determinado de pessoas reais, de carne e osso, no seio das condições desiguais das relações sociais no Brasil, em que o processo penal representa o sistema de imputação de culpabilidade como forma jurídica que emana das superestruturas jurídico-políticas de Poder, identificados pelo critério de classe para a definição do processo de criminalização que seleciona, desigualmente, a punição dos pobres, e a imunização dos poderosos.

Assim, inconscientemente - e de forma inútil (!) - o juiz inquisidor não aceita o caráter simbólico do direito e do processo penal, incapaz de processar e punir todos os fatos puníveis, isto é, a impunidade como constituição fisiológica e não patológica do sistema de justiça criminal e cria - para si e para os outros - nos chamados 'crimes do colarinho branco', os estereótipos e meta-regras que presidem também os processos criminais nos crimes tributários e nos crimes contra a ordem financeira, em que pese os tipos penais de caráter aberto, obscuros e indefinidos, que não raro se encerram na prescrição, pelo contraste entre as penas cominadas nos casos de sonegação fiscal de milhões e de furto e roubo de tostões.

Destarte, avançamos sobre as conclusões - parciais - de que, se o legislador produz a criminalização primária por meio do critério de classe, na definição dos bens jurídicos a serem protegidos e na intensidade de sua proteção, é na criminalização secundária, que compreende todo o sistema de justiça criminal (a polícia, a prisão e os tribunais), por meio do processo penal, que se consubstancia, no 'Estado de Direito', a criminalização seletiva e desigual de indivíduos sobre os quais pairam os indicadores 
sociais negativos de pobreza, miséria, desemprego etc.

\section{O CONTEÚDO DO PROCESSO PENAL: CRÍTICAS À TEORIA GERAL DO PROCESSO}

O discurso dominante no direito processual inaugurado por Oskar von Bülow, apresenta que o processo se constitui de uma relação jurídica distinta daquela estabelecida no campo do direito material, de caráter triangular e formada por três sujeitos: o autor, o juiz competente e o réu.

Outrossim, autores clássicos como José Frederico Marques afirmam que:

o processo penal é também um actum trium personarum, tal como o processo civil, e por isso nêle existem sujeitos parciais, ou partes, que atuam ao lado de um sujeito imparcial, ou juiz, em todo o curso do procedimento. (...) O juiz, figura central do processo, representa e encarna o Estado, na relação processual, como órgão jurisdicional a que incumbe aplicar os preceitos da ordem jurídica ${ }^{28} ;[\ldots]$ para compor a lide ${ }^{29}$.

Diz-se, de forma clássica, que no processo civil vige o princípio da verdade formal, ao passo que o processo penal é regido pelo princípio da verdade real.

A partir daí é que se legitima a atuação do juiz inquisidor, sob o argumento de que, no processo penal, em função do 'interesse público' e da ‘busca da verdade real' a qualquer custo, deve o juiz diligenciar em busca da prova, em prol da eliminação das dúvidas, afinal, tratar-se-ia da liberdade do acusado, ora objeto da verificação no processo penal inquisitório.

Todavia, Carnelutti já demonstrou brilhantemente que a verdade no processo

\footnotetext{
${ }^{28}$ MARQUES, José Frederico. Elementos de direito processual penal. Rio de Janeiro-São Paulo: Forense, 1961, p. 395.

${ }^{29}$ Idem. Tratado de direito processual penal. São Paulo: Saraiva, 1980. v. 2, p. 168.
} 
jamais pode ser real, diante da incapacidade do homem de apreendê-la e que talvez fosse apenas apreensível como verdade formal. Porém, é a partir do texto "Verità, Dubbio e Certezza", que o processualista enseja o ponto de partida para a negação da última, porque a primeira "jamais poderia ser alcançada pelo homem", com a destruição da falsa noção de verdade processual construída na Inquisição. A partir da constatação de que a verdade processual não existe, por se tratar de reflexo da verdade inatingível e intangível, Carnelutti propõe que no processo se busque e investigue a certeza $a^{30}$.

Deste modo, é relevante salientar a contribuição de Goldschmidt, o qual aduz que grave problema existe no paralelismo entre processo civil e processo penal, principalmente quando são buscadas categorias e definições do processo civil e pretende-se sua aplicação automática no processo penal ${ }^{31}$.

O fenômeno do processo civil é claro e distinto do que caracteriza o processo penal, do que decorre a necessidade de que haja o respeito às categorias jurídicoprocessuais próprias do processo penal, que ganha foros de autonomia em relação à origem clássica. Por tal razão, é que Lopes JR., ao se filiar à corrente teórica que advoga o caráter instrumental das medidas cautelares para garantir o normal desenvolvimento do processo, empreende a crítica ao senso comum teórico que, ao analisar os requisitos e fundamentos da prisão cautelar, identifica-o, numa aplicação literal do processo civil ao processo penal, com as categorias do fumus boni iuris e do periculum in mora.

Em primeiro lugar, o fumus identifica um juízo de verossimilhança quanto à probabilidade de existência do direito, o que não ocorre no caso da medida coercitiva, afinal, como se pode afirmar que o delito é a fumaça do bom direito se o delito é a

${ }^{30}$ CARNELUTTI. Veritá, dubbio e certeza ..., p. 5: "pertanto la mia strada, cominciata con l'attribuire al processo la ricerca della verità, ha messo capo alla sostituzione della verità con la certezza". [tradução livre: portanto a minha estrada, iniciada com a atribuição ao processo da busca à verdade, olvidou a substituição da verdade pela certeza].

${ }^{31}$ GOLDSCHMIDT, James. Problemas jurídicos y politicos del processo penal, p. 8. (Apud) LOPES JR., Aury. Introdução crítica ao processo penal: fundamentos da instrumentalidade garantista. 3. ed. Rio de Janeiro: Lumen, 2005, p. 193. 
negação do direito, sua antítese $?^{32}$

Em segundo lugar, para a decretação da medida cautelar, o periculum sequer seria requisito, mas fundamento. Todavia, o periculum in mora é visto como o risco derivado do atraso inerente ao tempo que deverá transcorrer até que haja uma sentença definitiva no processo. No processo penal, "o fator determinante não é o tempo, mas a situação de perigo criada pela conduta do imputado ${ }^{, 33}$.

Neste ponto, é prudente salientar as inúmeras decisões na práxis forense em que se vislumbra total ausência de fundamentação, em descompasso com o texto constitucional (art. 93, IX, da Constituição da República), reputáveis como decisão nula, quando não a própria ausência de decisão, por serem atos inexistentes e “incapazes para ingressar no mundo jurídico,34, tal a forma "tosca" em que se verbalizam, nos dizeres do mestre Aury Lopes Jr.

Assim, os juízes apóiam as sentenças criminais no discurso da teoria geral e unitária do processo, com a aplicação acrítica de categorias processuais civis no processo penal, constituindo verdadeiros requisitos retóricos da sentença ${ }^{35}$, a fim de imunizá-la do controle jurisdicional de sua motivação que é, por excelência, ideológica $^{36}$.

Por fim, na esteira das críticas à teoria geral do processo, cabe concluir com as

\footnotetext{
${ }^{32}$ Ibidem, p. 195.

${ }^{33}$ Ibidem, loc.cit.

${ }^{34}$ Ibidem, p. 198.
}

${ }^{35}$ BRUM, Nilo Bairros de. Requisitos retóricos da sentença penal. São Paulo: RT, 1980, p. xv: "pensamos que a ideologia é uma constante nas práticas jurídicas. Todas as tentativas no sentido de eliminá-la do plano da teoria resultaram em propostas redutoras que, longe de suprimi-las, incrementaram novas propostas ideológicas. Se temos de conviver com as ideologias, nada melhor do que enfrentá-las e assumi-las como realmente são. Reconhecendo a parcialidade de nossas ideologias e mitos, poderemos assumir uma postura mais lúcida, mais reflexiva, mais crítica, e, sobretudo, mais tolerante para com as ideologias alheias".

${ }^{36}$ PORTANOVA, Rui. Motivações ideológicas da sentença. Porto Alegre: 1990, p. 198: “a sentença, dada a sua especialíssima condição de exercício de poder por quem possua a indispensável formação acadêmica tem um dever social: difundir o jogo político contido no direito. (...) A motivação sentencial deve deixar clara a compreensão do julgador quanto à problemática ideológica no funcionamento da sociedade". 
lições de Miranda Coutinho, sobre a inexistência do conceito carneluttiano de lide no processo penal - um conflito de interesses qualificado por uma pretensão resistida sendo, portanto, inaceitável o conceito de lide no processo penal; o conteúdo do processo pode ser apresentado pela expressão caso penal ${ }^{37}$; para um conhecimento integral do caso penal no processo e sua relação com a jurisdição, propõe-se a transdisciplinariedade com o uso da psicanálise ${ }^{38}$, afinal, a sentença é o homem, por ele produzida e reflexo de sua ideologia, meta-regras e idiossincracias pessoais, e portanto é nele, ser humano, que se deve investir, sempre, com toda a esperança!

\section{A JUSTIÇA NEGOCIAL}

O movimento de "lei e ordem" instituído pela lógica da eficiência reproduz a ideologia do repressivismo saneador ao defender a supremacia estatal, o primado da lei e a "tolerância zero" em detrimento dos direitos e garantias individuais fundamentais.

Com o advento da lei 9.099/95 no Brasil, vislumbrou-se a adoção de um modelo de utilitarismo processual, baseado na eficiência e na aceleração antigarantista do processo penal, cujo resultado foi a instituição da plea negotiation norte-americana em terras tupiniquins.

No conflito garantismo vs eficientismo ensina Miranda Coutinho que "não é admissivel, em hipótese alguma, sinonimizar efetividade com eficiência, principalmente por desconhecimento. Afinal, aquela reclama uma análise dos fins; esta, a eficiência, desde a base neoliberal, responde aos meios ",39.

Com o aceleramento dos processos, conclui-se a decorrente

${ }^{37}$ MIRANDA COUTINHO, Jacinto Nelson de. A lide e o conteúdo do processo penal. Curitiba: Juruá, 1989, p. 152.

${ }^{38}$ Ibidem, loc. cit.

${ }^{39}$ MIRANDA COUTINHO, Jacinto Nelson de. Efetividade do processo penal e golpe de cena: um problema às reformas processuais. In: Escritos de direito e processo penal, p. 143 e ss. 
suspensão/exclusão das garantias de proteção do acusado, ou pelo menos, de redução de sua esfera de proteção.

Assim, trata-se a justiça negociada de uma modalidade de degeneração do processo, ou até de alternativa a ele, com a adoção de diversos instrumentos e atribuição de imensuráveis poderes ao Ministério Público, fundamentando-se em três argumentos principais para legitimar-se: a) estar em conformidade com o sistema acusatório; b) resultar da adoção de um "processo penal de partes"; c) proporcionar maior celeridade na administração da justiça.

Conforme aduz Ferrajoli, tais argumentos são totalmente ideológicos e mistificadores, para quem o sistema é fruto de uma "confusão entre o modelo teórico acusatório - que consiste unicamente na separação entre juiz e acusação, na igualdade entre acusação e defesa, na oralidade e publicidade do juízo - e as características concretas do sistema acusatório americano, algumas das quais, como a discricionariedade da ação penal e o acordo, não têm relação alguma com o modelo teórico ${ }^{, 40}$.

Evidentemente, a justiça negocial não faz parte do modelo acusatório, já que viola pelo menos seis princípios que sustentam o processo penal garantista ${ }^{41}$ :

a) Jurisdicionalidade: nulla poena, nulla culpa sine iudicio, representa o direito ao processo penal, à figura e ao estatuto do juiz, a exclusividade do poder jurisdicional, o direito ao juiz natural e submissão à lei praevia, scripta, stricta e certa;

b) Inderrogabilidade do juízo: denota a infungibilidade e a indeclinabilidade da jurisdição;

c) Separação das atividades de acusar e julgar: nullum iudicium sine accusatione;

${ }^{40}$ FERRAJOLI, Luigi. FERRAJOLI, Luigi. Direito e razão: teoria do garantismo penal. 2 . ed. São Paulo: RT, 2006, p. 747.

${ }^{41}$ LOPES JR., Aury. Justiça negocial: utilitarismo processual e eficiência antigarantista. Disponível em: <<http://www.aurylopesjr.com.br〉>. Acesso em: 01/03/2009. 
d) Presunção de inocência: de caráter absoluto, se projeta na garantia de presunção de não-culpabilidade até o trânsito em julgado de sentença penal condenatória;

e) Contraditório: nulla probatio sine defensione, instituiu o método de contradição da prova em juízo;

f) Fundamentação das decisões judiciais: representa a garantia de controle da racionalidade da decisão, de suas motivações e fundamentos.

Para além da violação ao pilar central do monopólio do poder legal e jurisdicional, a privatização dos conflitos intenta tornar o processo penal numa "negociata", em que a superioridade dos poderes do Ministério Público parece evidente, tal qual ilustram os dados apresentados por Figueiredo Dias e Costa Andrade $^{42}$, em que a plea bargaining nos Estados Unidos da América é responsável pela solução de $80 \%$ a 95\% dos delitos, isto é, em 8 ou 9 delitos a cada 10 sequer são processados com contraditório, no debate público e antogônico entre as partes, garantidas a igualdade de armas.

O processo se torna um instrumento de pressão que viola os compromissos democráticos com a tutela de bens jurídicos, tornando-se reduto de falsas acusações, blefes, ameaças para cooperar, delações premiadas, em que o promotor possui excessivo poder para transigir acerca direitos fundamentais indisponíveis, a tal ponto em que a razão e o saber são substituídos pelo poder atribuído ao Ministério Público ${ }^{43}$.

Por conseguinte, tem razão Guarnieri quando "afirma que acreditar na imparcialidade do Ministério Público é incidir no erro de 'confiar al lobo la mejor

${ }^{42}$ DIAS, Jorge de Figueiredo; COSTA ANDRADE, Manuel. Criminologia: o homem delinqüente e a sociedade criminógena. p. 484 e ss.

${ }^{43}$ LOPES JR. Justiça negocial ..., op. cit. 
defensa del cordero ",44.

E os fins não justificam os meios.

\section{CONSIDERAÇÕES FINAIS}

Segundo as brilhantes lições de Miranda Coutinho: "ora, se o processo tem por finalidade, entre outras, a reconstituição de um fato pretérito, o crime, mormente através da instrução probatória, a gestão da prova, na forma pela qual ela é realizada, identifica o princípio unificador" ${ }^{, 45}$.

A previsão no ordenamento jurídico dos poderes instrutórios do juiz na gestão da prova no processo penal brasileiro demonstram o princípio unificador do sistema inquisitório, traduzidos na possibilidade de o juiz, ex officio, decretar a prisão preventiva (art. 311, CPP); determinar o seqüestro de bens (art. 127, CPP); decretar a busca e apreensão (art. 242, CPP); ouvir outras testemunhas além das arroladas pelas partes (art. 209, CPP); proceder o juiz, interrogatório (art. 188, CPP), com nítida superioridade entre as partes, ao decidir a "pertinência e relevância" das perguntas e intervenções das partes, e por fim, a literalidade do art. 156 do Código de Processo Penal:

A prova da alegação incumbirá a quem a fizer, sendo, porém, facultado ao juiz de ofício:

(...)

II - determinar, no curso da instrução ou antes de proferir sentença, a realização de diligências para dirimir dúvida sobre ponto relevante.

É assim que, em essência, o sistema inquisitório permanece para nós, até hoje, quiçá porque sustenta o status quo e, portanto, serve a quem detém o poder em

\footnotetext{
${ }^{44}$ Ibidem, loc. cit.

${ }^{45}$ MIRANDA COUTINHO. Introdução aos princípios gerais ..., p. 168.
} 
qualquer regime, de modo que, a única solução para uma substancial reforma do processo penal brasileiro é, portanto, o abandono integral do sistema inquisitório, com o novo juiz no processo penal a figurar como garantidor da eficácia do sistema de direitos e garantias fundamentais do acusado no processo penal, com a assunção de sua postura ideológica de realizar a vontade da Constituição, e não de tornar o Processo Penal a instrumentalização do Direito Penal como "braço armado" da Constituição, ou melhor, da vontade do Poder.

Como disse o eminente Min. Eros Grau, em voto consignado na ADPF 144, "viver a democracia não é gratuito. Há um preço a ser pago por ela; em síntese, o preço do devido processo legal".

\section{REFERÊNCIAS}

ATIENZA, Manuel. As razões do direito: teorias da argumentação jurídica. Trad. Maria Cristina Guimarães Cupertino. São Paulo: Landy, 2006.

BARATTA, Alessandro. Criminologia crítica e crítica do direito penal: introdução à sociologia do direito penal. 3. ed. Trad. Juarez Cirino dos Santos. Rio de Janeiro: Revan, 2002.

BOBBIO, Norberto. O futuro da democracia: uma defesa das regras do jogo. Trad. Marco Aurélio Nogueira. 4. ed. Rio de Janeiro: Paz e Terra, 1989.

BRUM, Nilo Bairros de. Requisitos retóricos da sentença penal. São Paulo: RT, 1980

CAlAmandReI, Piero. Il Processo come giuoco. Rivista di Diritto Processuale, Padova, v. 5 (parte prima), p. 23-51, 1950.

CAPOGRASSI, Giuseppe. Giudizio processo scienza verità. Rivista di Diritto Processuale, Padova, v. 5 (parte prima), p. 1-22, 1950. 
CARNELUTTI, Francesco. Crisi della giustizia penale. Rivista di Diritto Processuale, Padova, p. 333-363, 1958. 1958. Responsabilità e giudizio. Rivista di Diritto Processuale, Padova, p. 1-13, . Verità, dubbio, certezza. Rivista di Diritto Processuale, Padova, v. 200, p. 49,1965 .

CARVALHO, Amilton Bueno de. Nós, juízes, inquisidores. Disponível em: <<http://www.aurylopesjr.com.br〉>. Acesso em: 01/03/2009.

CHAUI, Marilena de Souza. O que é ideologia?. 34. ed. São Paulo: Brasiliense, 1991.

CIRINO DOS SANTOS, Juarez. A criminologia radical. Rio de Janeiro: Forense, 1981.

COELHO, Luiz Fernando. Lógica jurídica e interpretação das leis. 2. ed. Rio de Janeiro: Forense, 1981.

CORDERO, Franco. Ideologia del processo penale. Milano: Giufreè, 1966.

. Guida alla procedura penale. Torino: Utet, 1986.

. Procedura penale. Milano: Giufreè, 1991.

DIAS, Jorge de Figueiredo. Direito processual penal. Coimbra: Coimbra, 1981.

; COSTA ANDRADE, Manuel. Criminologia: o homem delinqüente e a sociedade criminógena. Coimbra: Coimbra, 1997.

FARIA, José Eduardo. Ordem legal v. mudança social: a crise social do Judiciário e a formação do magistrado. Direito e Justiça: a função social do Judiciário. São Paulo: Ática, 1994.

; LIMA LOPES, José Reinaldo de. A função política do poder judiciário. Direito e Justiça: a função social do Judiciário. São Paulo: Ática, 1994.

FERRAJOLI, Luigi. Direito e razão: teoria do garantismo penal. 2. ed. São Paulo: RT, 2006. 
FOUCAULT, Michel. Vigiar e punir: nascimento da prisão. Trad. Lígia M. Ponde Vassallo. Petrópolis: Vozes, 1987.

GRAU, Eros. Ensaio e discurso sobre a interpretação/aplicação do direito. 2. ed. São Paulo: Malheiros, 2003.

HARTMANN, Érica de Oliveira. A parcialidade do controle jurisdicional na motivação das decisões. Dissertação de Mestrado. Faculdade de Direito da Universidade Federal do Paraná (UFPR), 2005.

KAFKA, Franz. O processo. São Paulo: Círculo do Livro, 1991.

LIEBMAN, Enrico Tullio. Fondamento del principio dispositivo. Rivista di Diritto Processuale, Padova, v. 15, p. 551-565, 1960.

LOPES JR., Aury. Introdução crítica ao processo penal: fundamentos da instrumentalidade garantista. 3. ed. Rio de Janeiro: Lumen, 2005.

A crise do inquérito policial: breve análise dos sistemas de investigação preliminar no processo penal. Disponível em: <<http://www.aurylopesjr.com.br >>. Acesso em: 01/03/2009.

Justiça negocial: utilitarismo processual e eficiência antigarantista. Disponível em: <<http://www.aurylopesjr.com.br〉>. Acesso em: 01/03/2009.

Prisões cautelares: fumus boni iuris e periculum in mora? Conceitos impróprios para o processo penal. Disponível em: <<http://www.aurylopesjr.com.br>>. Acesso em: 01/03/2009.

LYRA FILHO, Roberto. Por que estudar direito, hoje?. Brasília: Nair, 1984.

MAGALHÃES GOMES FILHO, Antônio. Direito à prova no processo penal. São Paulo: RT, 1997.

MARQUES, José Frederico. Elementos de direito processual penal. Rio de JaneiroSão Paulo: Forense, 1961.

Tratado de direito processual penal. São Paulo: Saraiva, 1980. v. 2.

MARX, Karl. La ley sobre los robos de leña. In: Escritos de juventud. México: Fondo de Cultura Econômica, 1987. 
MIAILLE, Michel. Introdução crítica ao direito. Trad. de Ana Prata. 2. ed. Lisboa: Estampa, 1989.

MIRANDA COUTINHO, Jacinto Nelson de. A lide e o conteúdo do processo penal. Curitiba: Juruá, 1989.

. Introdução aos princípios gerais do processo penal brasileiro. Revista da Faculdade de Direito, Curitiba, n. 30, p. 163-198, 2008.

O papel do novo juiz no processo penal. Crítica à teoria geral do direito processual penal. Rio de Janeiro: Renovar, 2001. p. 3-55.

Efetividade do processo penal e golpe de cena: um problema às reformas processuais. In: Wunderlich, A. (org.). Escritos de direito e processo penal em homenagem ao Prof. Paulo Cláudio Tovo Rio de Janeiro: Lumen Juris, 2002, pp. 139-147.

PERELMAN, Chäim; Olbrechts-Tyteca, Lucie. Tratado da argumentação: a nova retórica. Trad. Maria Ermantina de Almeida Prado Galvão. 2. ed. São Paulo: Martins Fontes, 2005.

PIERANGELLI, José Henrique. Processo penal: evolução histórica e fontes legislativas. Bauru: Jalovi, 1983.

PISAPIA, Gian Domenico. Compendio di procedura penale. 4. ed. Padova: Cedam, 1985.

PORTANOVA, Rui. Motivações ideológicas da sentença. Porto Alegre: 1990.

POULANTZAS, Nicos. O estado, o poder, o socialismo. Trad. Rita Lima. 2. ed. Rio de Janeiro: Graal, 1985.

RODRÍGUEZ, Victor Gabriel. Argumentação jurídica: técnicas de persuasão e lógica informal. 4. ed. São Paulo: Martins Fontes, 2005.

SABADELL, Ana Lucia. Tormenta júris permissione: tortura e processo penal na península ibérica. Rio de Janeiro: Revan, 2006.

SANTOS, Boaventura de Sousa. O discurso e o poder: ensaio sobre a sociologia da retórica. Porto Alegre: Fabris, 1988. 
TORNAGHI, Hélio. Curso de processo penal. 4. ed. São Paulo: Saraiva, 1987. v. 1.

TOURINHO FILHO, Fernando da Costa. Processo penal. 13. ed. São Paulo: Saraiva, 1992.

VÉLEZ MARICONDE, Alfredo. El proceso penal inquisitivo. Scritti giuridici in memoria de Piero Calamandrei. Padova: Cedam, 1958. v. 2. 